\title{
Meenutatud keel ja unustatud kiri: rahvalikud keelekorraldajad J. Hurda rahvaluulekogus ${ }^{1}$
}

\author{
Katre Kikas \\ Eesti Kirjandusmuuseumi folkloristika osakonna teadur \\ katreki@folklore.ee
}

\begin{abstract}
Teesid: Kas 19. sajandi lõpu kohalike rahvaluulekorrespondentide kirjapanekud kuuluvad suulisse või kirjalikku maailma? Ühelt poolt kätkevad nad endas suulise kultuuri teadmisi ja tõekspidamisi, ideaalis ka lauserütmi ja keelekõla. Teisalt jälle peegeldavad nad oma kirjapanijate soovi osaleda kirjalikul kommunikatsiooniväljal, eristada end suulisest/kirjaoskamatust/ebausklikust rahvast. Need kirjapanijad on vahepealsed, vahendajad - nad esindavad nn rahvalikku või rohujuuretasandi kirjalikkust (Fabian 1993; Barton \& Hamilton 2003).

Eriline on ka nende kogujate suhe keelega. Jakob Hurt palus, et lood ja laulud pandaks kirja nii nagu neid kõneldi, s.o kohalikus keeles. Ent ehkki nende kogujate jaoks oli kohalik murre kindlasti osa igapäevasuhtlusest, oli nende kirjalik kogemus (nii lugeja kui kirjutajana) seotud ühtse kirjakeelega. Seega tähendas rahvaluule kirjapanemine uutmoodi suhet kirjutatud ja suulise sõna vahel. Viimane aga tõi nii mitmelgi puhul kaasa selle, et kogujad üritasid seda suhet (suulise ja kirjutatud, kohaliku ja rahvusliku keele vahel) mõtestada ning nii mitmedki panid need mõtisklused ka kirja ja saatsid muude materjalide hulgas Hurdale.

Oma artiklis vaatlen kahe rahvaluulekoguja - Jaan Pindi (1843-1922) ja Hans Anton Schultsi (1866-1905) - kirjapanekuid. Need kaks ühtviisi väheharitud, kuid ometi viljakat korrespondenti on põnevad selle poolest, et lisasid kogutule ka erinevaid märkuseid ja tõlgendusi. Konkreetsemalt võtan vaatluse alla nende kirjutamise, kirja ja murdekeelega seotud arutlused.
\end{abstract}

Märksõnad: Jakob Hurt, rahvalik keelekorraldus, rahvaluule kogumine, Jaan Pint, Hans Anton Schults

19. sajandi lõpu kohalike rahvaluulekorrespondentide kirjapanekud on keelelises plaanis äärmiselt põnev uurimismaterjal - laveerivad need ju suulise ja kirjaliku, kohaliku ja üldrahvusliku keelekasutuse piirimail. Ühelt poolt kätkevad nad endas suulise kultuuri teadmisi ja tõekspidamisi, ideaalis ka lauserütmi ja keelekõla. Teisalt on see kõik paratamatult 'tõlgitud' kirjalikku vormi, kohandatud kaasaegse kirjakeele standardite ja võimalustega. Oma osa 
teksti lõplikus vormis mängis seegi, et ajal, mil toimus rahvaluule üleskirjutamine, polnud kirjakeel veel lõplikult paika loksunud ning johtuvalt vähesest kirjakultuuri kogemusest oli suure osa kogumistöös osalenute arusaam suulise ja kirjaliku keele vahekorrast võrdlemisi idiosünkraatiline.

Käesoleva artikli keskmes on kahe Jakob Hurda rahvaluulekorrespondendi - Hans Anton Schultsi ja Jaan Pindi - keeleteemalised kirjutised. Ehk siis: keskmes on see, mida arvasid kõneldud ja kirjutatud keelest kaks kolmeaastase kooliharidusega 19. sajandi keskpaigas sündinud meest. Mõlemad üritasid oma vähest formaalset haridusteed iseõppimise teel korvata ning ajakirjanduse tarbimine oli nende puhul üks oluline viis selle saavutamiseks. Nad mõtestasid endid selgelt rahvuslikena ning Jakob Hurda rahvaluulekogumises osalemine oli neile üks võimalus rahvuslikus plaanis midagi ära teha.

Selliste kirjutajate tegevuse analüüsimisel olen varasemalt kasutanud rahvaliku kirjalikkuse mõistet. Selle terminiga saab kõige üldisemalt viidata kirjutamispraktikatele, mis on kerkinud esile väljaspool kirjutamist levitavaid institutsioone (Barton \& Hamilton 2003; Fabian 1993). Mõiste iseenesest on lai ja hõlmab nii üldise kirjaoskusega ühiskondades levinud igapäevaelulisi kirjakasutusi (vt Barton \& Hamilton 2003; Sheridan \& Street \& Bloom 2000) kui ka seda, mida teevad eliidist väljapoole jäävad vähesed kirjaoskajad veel mitte täielikult kirjalikustunud ühiskondades (Fabian 1993; Barber 2006a, 2007; Van Toorn 2006; Laitinen \& Mikkola 2013; Kuismin \& Driscoll 2013). Käesolevas artiklis olen tuge leidnud just viimasesse rühma kuuluvatest uurimustest. Kontekstis, kus kirjaoskus pole veel päris valdav, tuleb esile üksikute kirjutada soovivate inimeste eripärane positsioon suulise ja kirjaliku maailma piiril, mis kindlasti mõjutab ka seda, milliseid valikuid nad kirjutajatena tegid, Taru Nordlund märgib näiteks, et nad: "sidusid kõneldud ja kirjutatud keele ressursse looval viisil" (2013: 138). Teisalt pööravad sellised kirjutajad sageli tähelepanu kirjutamisele kui sellisele - kirjutavad endast kui kirjutajatest, mõtestavad kirjutamise tähendust endi silmis jms (vt nt Kuismin 2013; Barber 2006b).

Rahvalikkus ei tähenda isolatsiooni nn peavoolus toimuvast - pigem tähendab see, et madala sotsiaalse positsiooni tõttu pole neil kirjutajatel võimalust tulevasi arenguid suunata, oma ideid laiema avalikkuseni tuua (Barber 2006b). Samas on nende kirjutatu sageli dialoogis ajakirjandusest või raamatutest loetuga. Kuivõrd rahvaluulekogumine oli väga tugevas seoses ajakirjanduse, s.o avaliku kirjaruumiga (just seal ilmusid nii üleskutsed kui ka aruanded), käsitlevad kogujad mõnikord rahvaluulekogumist kui poolavalikku ruumi, kui omamoodi kompensatsiooni reaalsele avalikkusele. Teadmine, et Hurdale saadetud materjale hoitakse tulevaste lugejate jaoks alles, andis vähemalt mingisuguse lootuse kunagi mõnes kontekstis lugeja leida (vrd Burns 2006; 
Mikkola 2013). Tõsi - rahvalike kirjutajate meediakogemus võib olla üsna katkendlik, johtuvalt sellest, millisele lugemisvarale neil oma geograafilises ja majanduslikus olukorras ligipääs oli.

Siinse artikli pealkirjas olen rahvaliku kirjalikkuse (ja sellega seotud rahvalike kirjutajate) mõistet mõnevõrra modifitseerinud - keskmes on rahvalik keelekorraldus, s.o see, mida on sellised kirjutajad arvanud keelest ja kirjutamisest kõige üldisemas mõttes. On võrdlemisi põnev, et Hurda nõue panna rahvaluulet kirja murdes mõjus mitmetele tema kaastöölistele inspireerivalt ning pani neid kirjutama hoopis üldisematel keelega seotud teemadel. Ka Kanni Labi on esile toonud, et Hurda kaastööliste hulgas on mitmeid "isehakanud keeleuurijaid-korraldajaid": kogumisaktsioonis osalemine "juhatas nii mõnedki kaastöölised rahvaluulet kirja pannes kokkupuutele eesti kirjakeele traditsiooni nõrkustega ja püüdele selles osas mingeid lahendusi leida" (2005: 39).

Nende kirjutajate arvamusavalduste juures on muidugi vaja meeles hoida, et Hurda rahvaluule kogumise aktsiooni toimumise ajaks ei olnud eesti kirjakeel veel üheselt paika saanud ning kirjutajad-lugejad puutusid kokku väga erinevate viisidega eesti keelt kirja panna. Tulisemad vaidlused uue ja vana kirjaviisi vahel olid toimunud küll juba mõned aastakümned varem (vt Kask 1945) ning lõppenud 1872. aastal asutatud Eesti Kirjameeste Seltsi otsusega kasutada uut kirjaviisi oma väljaannetes (Kask 1945: 94-99; Kingissepp 2001: 12). Reaalselt kasutati uut ja vana kirjaviisi veel pikalt paralleelselt - eriti just religioosne kirjandus kippus eelistama pigem vana kirjaviisi (piibel ilmus uues kirjaviisis alles 1889. aastal, vt Kask 1945: 98-99).

Seega võib öelda, et ajal, mil enamik hilisematest rahvaluulekogujatest õppis lugema, oli Piibel (jm usundiline kirjavara) veel vanas kirjaviisis, ilmalik kirjavara - sh ka ajakirjandus - uues. Paljudele vähem haritud inimestele oli üheks peamiseks ilmaliku lugemise allikaks ajakirjandus. Keelelise eeskujuna oli ajakirjandus aga mitmes mõttes ambivalentne lähtepunkt, kuivõrd see, kuidas erinevad ajakirjandusväljaanded seda (uut) kirjaviisi rakendasid, oli detailides erinev ning see erinevus polnud mitte vaikiv, vaid sageli saadetud tulistest (ja väga isiklikest) vaidlustest.

Näiteks kahe kõige rahvaluule kogumise sõbralikuma ajalehe - Postimehe ja Oleviku - toimetajad Ado Grenzstein ja Karl August Hermann, vaidlesid omavahel erinevatel kirjakeelega seotud teemadel. Aktsioonide algusaega jääb näiteks Grenzsteini kriitika Hermanni 1884. aastal ilmunud grammatikakäsitlusele (Grenzstein 1889a) ja samuti ohtralt keeleküsimusele tähelepanu pöörav arvustus Hermanni teosele "Häbelik Juhan" (Grenzstein 1889b). Ehkki keelekorralduse ajaloo jaoks on need kohati liigagi isiklikud näpuganäitamised ebaoluline pisiasi, siis väiksema kirjakultuuri kogemusega ajalehelugejatele võisid need nääklused olla fooniks, millelt nad kirjakeelt mõtestasid. 
Vaidluste kõrval pakkus ajakirjandus aga ka positiivsemaid keeleteemalisi mõttekohti - Olevik arutles näiteks eesti keele tulevikuväljavaadete üle (vt nt Grenzstein 1888, 1889c), samas kui Postimees avaldas mitmeid sarju eesti keele olemusest (nt sari "Eesti keel” 1888 aasta lõpus ning "Mõnda Eesti keelest" 1889. aasta alguses). Seda, et keeleteemad pakkusid ajalehelugejatele tõepoolest huvi, näitab seegi, et avaramaid keeleteemalisi arutelusid algatasid mõnikord ka ajalehtede kaastöölised, sh võisid sõna sekka öelda ka rahvaluulekogumisega seotud inimesed. Näiteks palus üks kirjasaatja ajalehe vahendusel Hurdalt kommentaari kuradi nime etümoloogiale ("Krati-raamatu" lugeja 1896) - Hurda ajalehes ilmunud vastust (Hurt 1896) kommenteeris-täiendas oma rahvaluule saadetise kaaskirjas aga kaastööline G. Tikerpuu (H III 23, 879/82) (ühe rahvajutu etümoloogilisest tõlgendusest lähtuvat arutelu vt ka Kikas 2016).

\section{Rahvaluule kogumine ja keel: rahvuslik vs teaduslik keelekäsitlus}

Minnes avarama meediamaastiku juurest konkreetselt rahvaluule kogumise juurde, s.o selle juurde, kuidas käsitleb oma üleskutsetes ja aruannetes keeleküsimust Jakob Hurt, siis paistab silma, et keele roll selles kontekstis on mõneti teine, kui avalikus ruumis üldiselt. Kui viimases käsitletakse keelt seotuna konkreetse rahvaga (igal rahval on oma keel), siis rahvaluule kogumise kontekstis on tähelepanu rahvusest väiksematel üksustel (kihelkond, vald, küla). Rahvus on kui omamoodi mosaiik nendest erinevatest kildudest. Selle mosaiigi näitlikustamiseks kasutab Hurt sageli kaardi kujundit, kõneldes sealjuures, et kaart on täiuslik vaid siis, kui selle kõik osad on ühtlaselt kogujatega kaetud. Teiseks erisuseks on, et kui rahvusliku diskursuse keskmes on kirjutatud keel (sest just kirjakultuur on see, mis ühe rahvuse tõeliseks teeb), siis rahvaluule kogumise keskmes on nõue panna kõik kirja nii nagu rahvas räägib "kirjakeele pääle vaatamata ja sellest segamata" (Hurt 1989: 46). Väga tugevalt üldistades võib öelda ka, et avalikus ruumis domineerib keele rahvuslik, rahvaluule kogumise kontekstis (eelkõige Hurda kirjutistes) aga teaduslik käsitlus - see on aga tõesti väga tugev üldistus, kuna reaalsuses apelleerib ka meedia teaduslikkusele ning Hurt rõhub oma kaastööliste rahvuslikele tunnetele.

On väga põnev jälgida, kuidas Hurt oma kirjutistes teaduslikku ja rahvuslikku poolt balansseerib. Nii alustab ta näiteks oma 1888. aastal ilmunud üleskutse "Paar palvid Eesti ärksamaile poegadele ja tütardele" (1989: 45-56) sissejuhatust viitega kogumistöö teaduslikule kasule, seejärel toob aga sisse rahvusliku kohuse küsimuse: "Ühtlasi on see töö üks isamaa kohus. Meie langeme kange laituse alla, kui selle kohuse ära unustame” (Hurt 1989: 45). 
Järgneb kaks palvet, neist esimene pühendatud murretele ja teine rahvaluulele, mõlemas domineerib teaduslik raam. Näiteks murdekeelele pühendatud palve alguses juhib Hurt lugejate tähelepanu just murdekeele teaduslikule väärtusele:

Minu esimene palve käib Eestikeele kohta. Üks keel saab siis alles täiesti tuttavaks ja selgeks, kui tema murdeid ehk külade ja kihelkondade kõneviisi hästi tuntakse. Teaduslikuks keeleuurimiseks on murrete tundmist hädaste tarvis ja otse murretes on palju teaduse tuuma. Eestikeele murrete uurimine ei ole veel kaugele jõudnud, meil tuleb veel palju tööd teha, enne kui täielise Eestikeele murrete pildi ja kaardi võime teha ja keeleuurimise põllul muude kõrva astuda (samas: 46).

Rahvaluule kogumisele keskenduva osa alguses rõhutab ta aga ühistöö olulisust teaduslike teadmiste loomises: "Pisukestest liivaterakestest on kõrged mäed loodud; nõnda ehitab ka uurija inimese vaim teaduse terakestest kauni ja nägusa teaduse templi üles" (samas: 47).

Muuseas need kaks palvet olid suunatud mõnevõrra erinevatele auditooriumidele. Rahvaluuleteemaline üleskutse oli suunatud kõigile "kes iganes sulge oskavad pruukida" (samas: 47), murretele tähelepanu juhtiv pool aga pigem haritumatele inimestele "kes kirjatööga enam on harjunud, nimelt ka meie emakeele iseloomu teravamine tähele on pannud" (samas: 47). Ehk siis: töö esialgses faasis pidas Hurt murdekeelega seotut vähem haritutele üle jõu käivaks. Reaalse töö käigus sulasid need palved aga kokku - Hurt rõhutab aruannetes, et 'parimaks sisuks murdenäitele on rahvajutud', ning õhutab kõiki kogujaid - olenemata nende haridusest - lugusid 'murde mundris' kirja panema.

\section{Rahvaluulekogujad ja kirjutatud keel: murdekirjapanekust rahvaliku keelekorralduseni}

On toodud esile, et väheõppinud kirjutajad lähtuvad kirjutades pigem lugemiskogemusest kui sellest, kuidas nad kuulevad enda ümber kõneldavat (Kauranen 2009: 17; Laitinen 2013: 276). Soome uurija Lea Laitinen on oletanud, et see viitab kirjutajate soovile samastuda "oma kohalikust kõnekogukonnast laiema rahvusliku keelekogukonnaga” (Laitinen 2013: 276), s.o teatud keelekuju kasutamine andis võimaluse näidata oma rahvuslikkust. Valikuid mõjutas muidugi ka see, millises kirjas olid kirjutatud kooliõpikud, aga ka see, mis kontekstis ja kellele kirjutati - eriti just avalikus ja/või kõrgema sotsiaalse staatusega inimestega suheldes võis püüd standardi poole olla tugevam kui erakirjades (Laitinen 2013: 276). 
Seega: nõue 'kirjutada nii nagu räägitakse' tähendas kogujatele vajadust kirjutada viisil, kuidas nad polnud seda varem teinud. Seega pole eriti ootamatu, et nii mõnedki nendivad kaaskirjades, et murdes kirjutamine käib neile üle jõu. Aednik G. Tikerpuu isegi tunneb, et tema võimetus kodumurret kirjutada justkui näitaks halba suhtumist oma päritolupaika (on üsna põnev jälgida, kuidas selles lõigus toimub justkui muidu mitte-prestiižse kirjaviisi väärtuse muutus $^{2}$ ):

Palun vabantada, et ma mitte küla murrakus ei kirjutanud, aga ma ei tahaks seda isigi uskuda et inimene kodu kolded mustab, siiski on tõsi et mull palju raskem Hiiu murrakud on kirjuta, kui nii ma viskasin juba 2 poognad nurka kus teise sõna peal teise pääl ja kolmantama peal kirjutasi. Kes rohkem kirja tööd teeb sellel on muidugi kergem, mull tahab aga harjutust... (H III 23, 886).

Samas ei tähenda kurtmine seda, et teistmoodi kirjutada ei üritata - Hurda korrespondentide kirjapanekuid just murdeuurimuse seisukohast vaadelnud Kadri Peebo ja Juhan Peegel on välja toonud, et ka vähemharitud kogujate hulgas oli väga terava kõrvaga ja hea keeletajuga kirjutajaid (Peebo \& Peegel 1989: 5-10). Põnev on aga see, et sageli kaasnevad kõneldud keele täpse jälgimise ja üleskirjutamisega mõneti ootamatud kõrvalmõjud - katsed anda kirjas edasi kõnekeele pisimaid nüansse panevad kogujaid ka kirjakeelt hoopis teise pilguga vaatama. Näiteks kirjeldab T. Tetsmann oma murde kirjapanemise kogemusele järgnenud nördimust kirjakeele üle nii:

Nagu kirjast näete olen ma püin nõnna viisi kirjutada, kudas rahvas siin räägib (mõned veiksed viad jäägu arvamata) et ta aga praeguse kirja keele vassdu on, selle pärast oleks veel kirjanikkudega kissmest küll olevad, kui ma oleks aga isi rohkem kirjanikuks õppind olema, et ma võiks ja mõesdaks neile õigel kohal vasdu akata [---] Vaadake kirjanikud, miks pärast kirjutate teie, maksud, metsad, lapsed, läksid, püksid?---

Kas se kirja täht s tõeste nii maias on, et ta ei mingisugust pehmed tähhdi oma ligi ei salli (kannada) või on paberil süid? Rahhva keel aga kis kõik apud ja magedad maitseb, ei põllga sugugi välja üdeldes nägu magsud, medsad, labsed, lägsid, pügsid. j.n.e. Niisuguste asjade pärast oleks mul paelugui rääkimest olevad, aga mine ilma õppetama, nii paelu olgu aga oma vahel ütelda, et kõik raamatud ja ühentuse kirjad ei aita midagi, kui mette rahva äält tähele ei panda (H II 20, 820).

Siin lõigus on kätketud üks rahvaliku keelekorralduse keskseid küsimusi: miks erineb kirjakeel nii palju sellest, kuidas rahvas reaalselt (siinses kandis) räägib? Ehk siis: vähese haridusega kirjutajate arusaam sellest, kus paikneb 
piir murde ja kirjakeele vahel, on sageli väga hägus. Näiteks kirjutab Kanni Labi rahvaluulekoguja Jüri Ustallo keeleteemalistele seisukohtadele keskenduvas artiklis: "Kirjakeele küsimustes olid Ustallol küll tugevad murdepõhised eelarvamused, ent samas olid tal ka kirjakeelepõhised eelarvamused oma kodumurde suhtes" (Labi 2005: 56, vt ka samas: 54, kus ta toob teisigi näiteid sarnasest segadusest). Labi nendib, et selline kodumurde põhjal üldkeele hindamine oli omal kombel paratamatu: "Maamehe puhul, kel tõenäoliselt kuigi palju võimalust ei olnud kodumaal ringi rännata ja eri murdeid kuulda, on see ehk loomulikki" (samas: 41-42).

Lisaks kohaliku murde kesksusele ühendab rahvalikke keelekorraldajaid seegi, et suhestatuna Hurda teadusliku ja meedia rahvusliku lähenemise vahel jäävad nad pigem meedia poolele. Ehkki võimalus olla teaduslikus mõttes kasulik on paljude kogujate silmis vägagi paeluv, ei tunne nad end selles valdkonnas kuigi kindlalt - või kui nad ka rõhuvad mingitele teaduslikele aspektidele, siis on tegu üsnagi katkendlike uues kontekstis ületõlgendatud üksikfaktidega. Pigem rõhutavad nad just kogumistöö rahvuslikku olulisust, sealjuures võis rahvaluule kogumises esil olev rahvuse kujutlemine mosaiigina aidata nii mõnelgi kogujal rahvusmõiste abstraktsusega toime tulla.

Järgnevalt vaatlen lähemalt kahe rahvaliku keelekorraldaja kirjutisi. Näideteks olen valinud kaks eri põlvkonda kuuluvat vägagi erineva elukogemusega inimest: Koerust pärit rätsepa Hans Anton Schultsi ja Võnnust pärit ja noorpõlves Samaarasse kolinud põllumehe Jaan Pindi. Neid mehi ühendab võrdlemisi lühike haridustee ning soov sellest hoolimata ühiskonnaasjades kaasa rääkida, kirjalikus meediaruumis osaleda. Rahvaluule kogumine on mõlema puhul selgelt rahvusliku tähendusega ettevõtmine, ehkki Schultsil on rahvuslus ambivalentses suhtes kodukohapatriotismiga, samas Pint asetab end kui väljarändajat "paremini nägeva eemalolija” positsioonile.

Schults ja Pint lisavad sagedasti pärimuspaladele erinevaid kommentaare - nad ilmselgelt ei soovi olla üksnes üleskirjutajad, vaid püüavad asetada kogutava mingisse mõtestatud raamistusse. Antud hetkel on keskmes need kirjutised, kus nad pööravad lähemat tähelepanu keelele ja/või kirjale. Järgnevas ei ole mu eesmärgiks anda hinnangut sellele, kui head murdetundjad nad olid või kui täpselt/autentselt suutsid edasi anda keelt, mida väitsid end kirja panevat. Käsitluses keskendun eelkõige erinevatele piiritlustele, mille nad ise oma kirjutistes esile toovad, sh näiteks eristused suulise ja kirjaliku, kohaliku ja rahvusliku, kaasaegse ja vana vahel. Sellest tulenevalt kasutan ka nende eristatud allkeeltele viitamisel nende endi antud nimetusi ega loo otseselt seoseid tänapäevase terminoloogiaga. 


\section{Hans Anton Schults: kiri ja rahvus}

Hans Anton Schults (1866-1905) on pärit Järvamaalt, Koeru kihelkonnast, Väinjärve vallast, Vaali külast. Ametilt oli ta külarätsep, kuid on teateid, et ta tegutses ka rändraamatukaupmehena. Oma hariduse kohta on ta ise Hurdale kirjutanud: "Mina ei ole kihelkonna ega "real" koolis käind ja ainult aga mõni päävake Valla ehk küla kooli pingi peal istund" (H II 39, 11). Siiski on teada, et ta hiljem üritas iseseisvalt edasi õppida. Aastatel 1887-1889 oli ta sõjaväeteenistuses Viiburis, sealt naasis ta haigestumise tõttu ennetähtaegselt (oma sõjaväekogemusest on ta kirjutanud H II 67, 451/66). 1905. aasta revolutsioonisegaduses rajas ta kaaslastega Vaali vabariigi (ise sai ta selle presidendiks), sama aasta jõululaupäeval lasti vabariigiloojad aga karistussalga poolt maha (Vaali vabariigi kohta vt Koeru 1935).

Hurda rahvaluule kogumise aktsiooniga liitus Schults pärast haigusest paranemist 1890. aastal, ning kuni 1903. aastani saatis ta Hurdale 2284 lehekülge erinevaid kirjapanekuid - sealhulgas nii laule, lugusid ja lühivorme kui ka igasugu kommentaare pärimuspaladele, trükis avaldatud pärimustekstidele, nende töötlustele ja tõlgendustele (ülevaadet saadetistest vt Kikas 2010b: 1416). Rahvaluulet kogus Schults peamiselt Koeru kihelkonnast, kuid mõnevõrra ka muudest Järvamaa piirkondadest.

Richard Viidalepp (1982: 260) on esile tõstnud, et Schultsi kirjapanekud on tehtud "tolleaegses kohalikus keelemurdes". Schultsi murdekirjapanekute kvaliteedile viitab seegi, et murdetekstide kogumikus "Igal puul oma juur" on Koeru kihelkonna näideteks just tema kirjapanekud (vt Peebo \& Peegel 1989: 138-141). Seevastu folkloristid on Schultsi kirjapandu autentsuse osas mõnevõrra kahtlevad - põhjuseks see, et väga suur osa kirjapanekutest on pigem Faehlmanni mütoloogia arendused kui suulist algupära (erinevaid arvamusi tema kogutust vt Loorits 2000; Viidalepp 1892; Kikas 2007).

Schults ise rõhutab kaaskirjades, et lood on kirja pandud nii nagu vanakesed neid rääkisid: "Siin korjanduse sees saab kõik jüttud nanda rahva keele painutuse järele kirjutud. Ja nanda ülesse tähendud kuida inimeste suust olen kuulnud" (H II 39, 11). Laias laastus võib Schultsi kirjapanekutes eristada kolme keeletasandit. Kõige selgemalt eristatud on allikate keel, millele ta viitab kui 'vanale järva keelele' (s.o ta ei erista erinevate külade või kihelkondade keelepruuki). Selle kõrval on keel, milles ta kirjutab oma tekste (kaaskirju, arutlusi). See keel on suhteliselt lähedane allikate keelele (vt nt ülaltsiteeritud lõik - jüttud, nanda) - seega ei pea tema puhul päris paika väide, et vähem haritud orienteeruvad kirjutades pigem kirjakeelele. Kahjuks pole mul võrdluseks ühtegi Schultsi kirjutist, mis oleks kirjutatud väljaspool rahvaluule kogumise konteksti - oleks huvitav näha, kas ja kui palju paistab sealt välja tema Järva taust ${ }^{3}$. 
Foto 1. Hans Anton Schults vormistas oma mahukamad saadetised raamatutena. Siin esimese korjanduse tiitelleht, millel ta endale viitab kirillitsas initsiaalidega (H II 39, 9).

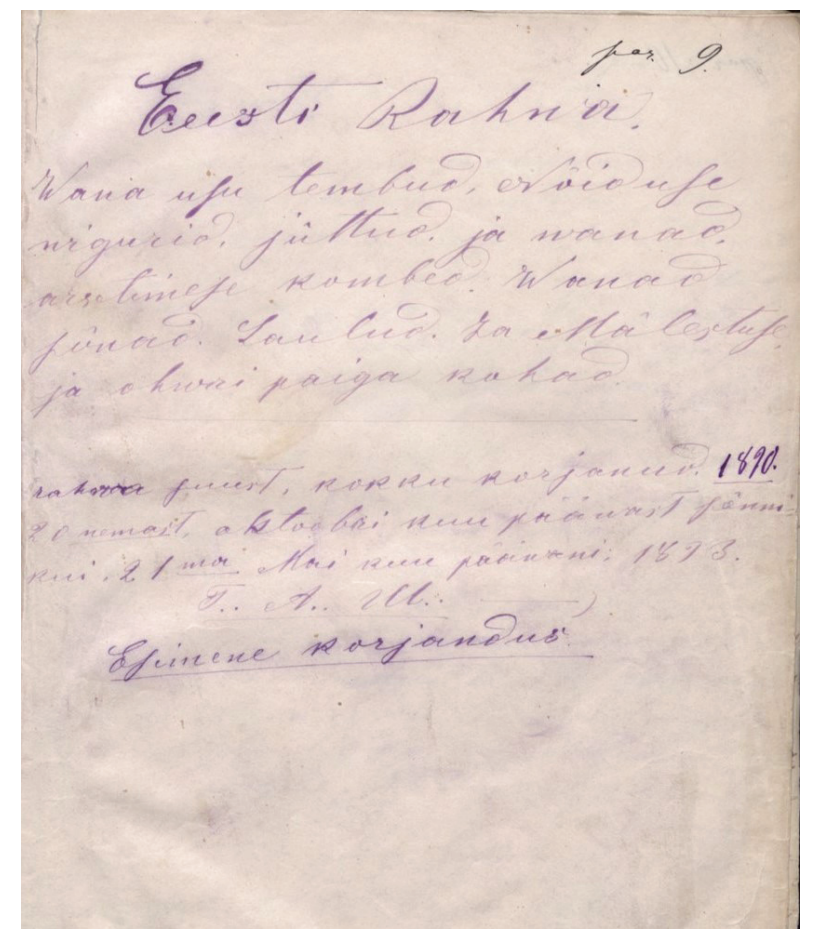

Kolmandaks on kirjapanekutes aga viiteid-vihjeid kirjakeelele, täpsemalt sellele, mida Schults tajub kui üldiselt mõistetavat keelt (nime ta sellele ei anna). See tasand ilmub kirjutistes eelkõige erinevate sulgudesse paigutatud keeleliste täpsustustena:

Kui saa uut aita teed, siis raiu iga aida oampalgi otsa, viide-nurka märk ehk rist, ja löö hobuse raud vasta-oksi (see on voagi (aagi) pooled ülespidi[)], aida ukse alla, põranda külge. Siis tont ei soa sinu aidest villa (vilja) varastada, ega piase aita, ega soa nõid sinu leiva jätku ära lausuda (H II 39, 18/9 (6)).

Nimetus 'vana järva keel' ilmub Schultsi kirjutistes esmakordselt 1891. aastal kirjapandud murdeteemalises arutluses. Arutluse lähtepunktiks on tõdemus, et vana järva keelt ei ole võimalik kasutadaoleva tähestikuga kirja panna:

Ka annab meile Vana Järva maa keele murre selgesti tunda, et mitte praeguse Eesti keele tähtedega teda õieti ei saa kirjutada, vaid et hääl isi enesest piab tähte muutma, mis mitte kirjas leida ei ole (H II 39, 101).

Samas möönab ta aga, et see probleem tekib just vana järva keelega, - kaasaegne keel on aja jooksul kirjaga kohandunud: "sest et meie aal keel ja sõnad tähtede järele lühikeseks ja kõlavaks tehakse“ (H II 39, 101). Põhjust, miks 
kõne ja keel nõnda lahku lähevad, näeb Schults selles, et eestlastel pole OMA kirjasüsteemi:

Kuna Vene ja Saksa rahval oma keele järele tarvilised tähed on kirjutud. Meie Eesti rahval ei ole seda mitte! On üks hääleta täht ehk poole häälega täht vaia, siis piame seda kohe võera keele tähtede hulgast lainama ehk täie häälelise pookstaviga kirjutama, kui lainu ei taha teha, ja ka võera keele tähed ei kõlva iga kord võtta, vaid Eesti keele poole häälega kirjas tähed tarvitavad jällegi isesugust hääle kõla. Miks ei või siis eesti keele tähestik nii suur olla? (H II 39, 102).

Viide oma kirjasüsteemile on põnev seetõttu, et sellega liigub Schults kohalikult tasandilt rahvustasandile, s.o ei räägi mitte järva, vaid eesti keelest, viidates nii justkui sellele, et kirja ja kõne vaheline lõhe on omane ka teistele eesti keele murretele. Ka järgmises lauses viitab ta Järvamaast mõnevõrra avaramale piirkonnale:

Vana Järva maa keele murre oma keele väänete ja käänudega tarvitab umbes (45) nelikümmend viis kirja tähte, ja viis rõhu märki, aga rannarahva vana keel tarvitab vel rohkem tähti ja märkisi (H II 39, 102).

Seejärel naaseb ta aga kitsalt Järvamaa näite juurde ja asub andma ülevaadet vana järva keele eripäradest. Mõnede näidete puhul on keskmes pigem vanade järvakate eripärane suhtlusstiil - viimast iseloomustavad näiteks luulekeelsed dialoogid ja hoogsõnad. Kuid on ka puhtalt kirjapanekuga seotud probleeme, millele ta viitab üldistavalt kui 'keele veanetele (väänetele)'. Nende hulka kuulub näiteks homonüümide eristamine (moa ja ma, vt H II 39, 106), ning tavalise ja pehmendatud n-i eristamine:

1. "Oi vennike” mitte kui vennike, vaid siin piab üks hääle täht jänn olema, et mitte ee üksi ei ole, vaid pool ee ja pool ii-d, siis tuleb see sõna õieti välja.

2. "Kañn" mitte kui kann. Kann on joogi riist, aga kañn on lilleke ehk nagu mängu asi, siis tuleb õige vahe, et mitte kañn ega kann ühe nimelised asjad ei ole, vaid hääl teeb siin selge vahe, aga seda tähte, mis pool aa-st ja pool häält ii-st annaks ei ole meie keeles ja selle pärast piame kohe kañn, mängu asi, ja kann, joogi riist, ühte moodi, ja ühe tähtedega kirjutama, aga kõnes on ommeti selge vahe tunda, mis kañn ja kann on (H II 39, 105).

Ning pikkade vokaalide diftongistumine:

Keanama - käänama

Veanama-väänama [---] 
Kõik need esimesed sõnad tarvitavad ise sugusid tähti, enne kui nende õige hääl välja tuleb (H II 39, 108).

Arutluse lõpetab Schults lubadusega, et kõik lood saavad kirja pandud nii nagu rahvas räägib:

Meie aga tahame kõik, juttud, vana usu punktid ja vanad kombed nii kirjutada, kuidas neid inimesed just räägivad, ja sial ja saab veel rohkem neid sõnu kuulda, meil ei ole tarvis siin pikkemalt sõnu arutada (H II $39,108)$.

See arutlus on ainus pikem kirjutis, kus Schults kohalikku keelt analüüsib, lisaks sellele kohtame tema kirjapanekutes aga ka mitmeid üldisemalt kirja ja kirjutamist puudutavaid mõtteavaldusi. Nimelt on Schults veendunud, et vallutuseelse aja eesti kultuur oli raamatukultuur ning väga paljud tema kirjapandud lood keskenduvad ühel või teisel moel neile muistsetele raamatutele (vt Kikas 2010a, 2010b). Põhjus, miks ma seda hetkel esile toon, on selles, et ka ülal käsitletud murdeanalüüs järgneb pikemale muistsete raamatutega seotud lugude tsüklile. Vahetult arutlusele eelneb lugu eestlaste külaskäigust tiiruse ${ }^{4}$ rahva juurde, mis lõppeb oletusega: "Nanda võib siis ka väga võimalik olla, et meie rahva ja vana Tiiruse rahva kirja tähed ühed olid" (H II 39, 101). Ilmselt just seda hüpoteesi tuleb meeles hoida, lugedes mõtisklusi sellest, et kaasaegne keel ei võimalda vanapärast keelt kirja panna - kõige lähteks on eeldus, et see vana kirjakultuur oli kirja pandud mingis teises (kõnele lähedasemas) kirjasüsteemis. Ka arutluse keskel olev põige üldisemale rahvustasandile (eesti rahval pole oma kirja) seob arutluse just nende varasemate lugudega (mis ei käsitle mitte Järvamaad, vaid eesti rahvast kui tervikut), selle raamistuse kontekstis on aga ootamatu Schultsi mööndus, et tänapäevane kõne on selle võõra tähestikuga kohandunud. Igatahes on märkimisväärne, et sellise olemuselt pseudoajaloolisse (-folkloori) valdkonda kuuluvate lugude kaudu jõuab ta kohaliku murdekeele (ilmselt vägagi asjaliku) kirjelduseni.

Schultsi hilisemates 1903. aasta kirjapanekutes on aga kaks mõnevõrra kurioosset katsetust kirjasüsteemidega. Neist esimene on Teise korjanduse sissejuhatus, mis muuseas käsitlebki kohaliku keele kirjapanemise küsimust. Tekst on kirja pandud eesti keeles, aga osaliselt kirillitsas - mis on sellise valiku tinginud, jääb paraku lahtiseks, sama saadetise rahvaluule materjal on ladina tähestikus (H II 67, 1). Teine näide pärineb samal aastal koostatud Kolmandast korjandusest, kus muuhulgas pikem kirjutis, mille lähtepunktiks on üks konkreetne lugemiskogemus: A. H. Sayce'i raamatu "Piibli ajalooline tõde. Egiptuse, Assiria, Palestiina ja Väike-Asia muinasleiduste valguses” (1900). Raamatus 


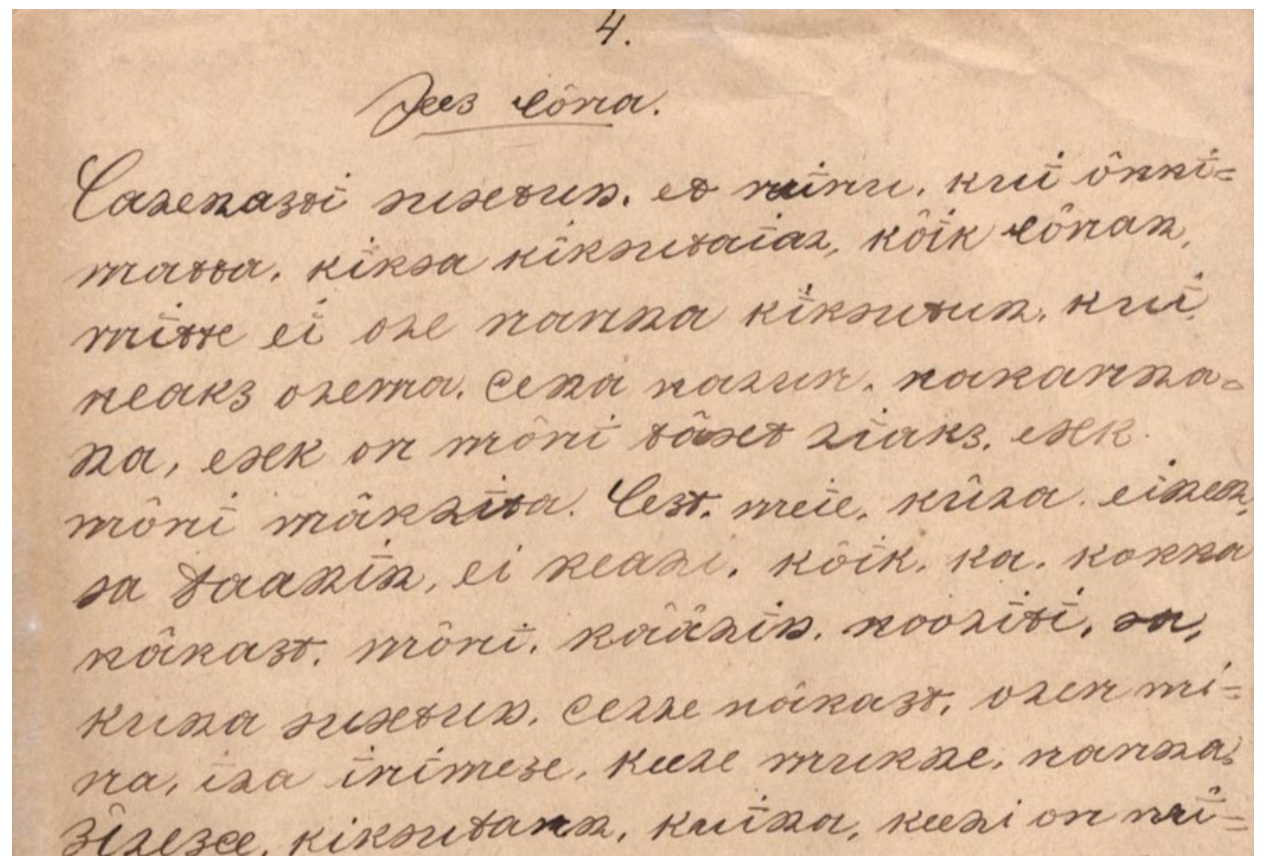

Foto 2. Hans Anton Schultsi teise korjanduse eessõna algus. Kirjutatud osaliselt kirillitsas (H II 67, 1).

tutvustatud erinevate vanade kultuuride kirjastiilid on osutunud Schultsile äärmiselt inspireerivaks ning arutluses võrdlebki ta vanade akkadlaste kirja eesti peremärkidega. Jääb mõnevõrra arusaamatuks, kas ta näeb nende vahel geneetilist sidet, või pigem apelleerib analoogiale (sarnase välimusega märgid võivad olla ka sama funktsiooniga) - igatahes näib, et tänu sellele lugemiskogemusele astus ta oma vaimus pika sammu otsitud vanale kirjale lähemale (H II 68, 261/89). Ehkki selliseid arutlusi näib võrdlemisi lihtne liigse ekstsentrilisusena kõrvale jätta, on siiski oluline näha, et tema kaasajas tegelesid sellise erinevate rahvuste vaheliste sarnasuste (ja võimalike sugulussuhete) otsimisega ka mõnevõrra haritumad inimesed - tuntuim on näiteks K. A. Hermanni käsitlus eestlaste ja sumerlaste sugulusest (Hermann 1896), kuid mõni aasta enne seda teost ilmus ajakirjanduses Jaan Jungi artiklisari "Eesti keele jäljed Idamaal” (1894). Tõsi - nii Hermann kui ka Jung toetuvad keelelistele sarnasustele, Schultsi eripäraks on soov jõuda vana kirja ja raamatuteni. 


\section{Jaan Pint: väljarändaja kodukeele kõla}

Jaan Pint (1843-1922) on pärit Võnnu kihelkonnast Ahja vallast põllumehe perekonnast. Haridust oli temalgi külakooli jagu, ehkki kooliõpetaja üritas isa veenda, et ta ka kihelkonnakooli saadetaks (EKLA f 43, m 17: 38, l 1/4), oma hilisemat iseõppija teed on ta kirjeldanud Hurdale saadetud eluloos (EKLA f 43, m 17: 38, l 2/3-2/4, 3/5-3/6). 1863. aastal rändas ta koos perekonnaga Samaarasse Estonka külasse, kus jätkas põllumehena. Rahvaluulet hakkas Pint koguma 1888. aastal, kohe kui Hurt oma kampaania käima lükkas; kuni 1895. aastani läkitas ta Hurdale rahvaluulet seitsmel korral (lisaks Hurdale on ta teinud koostööd ka Eesti Üliõpilaste Seltsi ja M. J. Eiseniga). Suurem osa materjalist on saadud teistelt samas piirkonnas elavatelt väljarändajatelt, väiksema osa on pannud kirja oma mälestuste järgi. Tema kogude põhjal võib järeldada, et külas elas väga erineva piirkondliku taustaga inimesi.

Konteksti mõttes mainin ära, et Pindi kõrval oli Hurdal veel teisigi idadiasporaas (mõiste kohta vt Jürgenson 2012: 9) elavaid korrespondente, sh nii neid, kes juba asunduses sündinud kui ka neid, kes sarnaselt Pindiga kogumistöö alguseks aastakümneid Balti kubermangudest eemal olnud. Aivar Jürgenson on välja toonud, et 19. sajandi keskpaiga väljarändajad lahkusid ajal, mil rahvuslik ärkamine oli juba hoo sisse saanud, ning rahvuslikud ideed leidsid koha ka uutes asupaikades. Kuna asundustesse telliti eestikeelset ajakirjandust ja raamatuid ning ka kooliõpetus oli eestikeelne, võib öelda, et kuni 1920. aastateni elasid idadiasporaa eestlased eestikeelses meediaruumis (Jürgenson 2015: $33-34,36$ jj). Ka Pindil ei olnud rahvaluulekogumine esimene kord rahvuslikes ühisettevõtmistes osaleda, näiteks saatis ta kaastöid Eestis ilmuvatele ajalehtedele ning elas tuliselt kaasa Aleksandri kooli kampaaniale (EKLA f 43, $\mathrm{m}$ 17: 38, 1 3/6). Oma esimese rahvaluulesaadetise kaaskirjas väljendab ta siirast heameelt selle üle, et Hurt on vahepealsest mõonnaperioodist üle saanud ja rõhutab, et Samaara eestlased on alati just temasse uskunud:

Meie "Samaarlased" kelle veel isamaa ja oma rahvas kallis on; oleme kaugelt paljo peenema pilguta ja palavama pisaraga isamaa õnne ja õnnetust kaalunud; selleks oleme me Teid, kui kõige õiglasemad ja targemad tüürijad; tunnistanud (H III 16, 490).

Ka hilisemate korjanduste kaaskirjades on mitmeid Hurta ülistavaid lõike, mis sageli toovad esile Hurda rolli emakeele edendajana:

Teie olete isamaale ilusama õiedega lillekeisi pü̈̈dnud istutata; rahvuse õigusid ülendanud ja ühitusele sidunud, Oma sugurahva elo olu ja õigusi, meeld ja keeld kosutanud; seda tunnevad kõik kes oma isamaad, rahvast, usku ja Emakeeld kalliks peavad (H III 16, 524). 


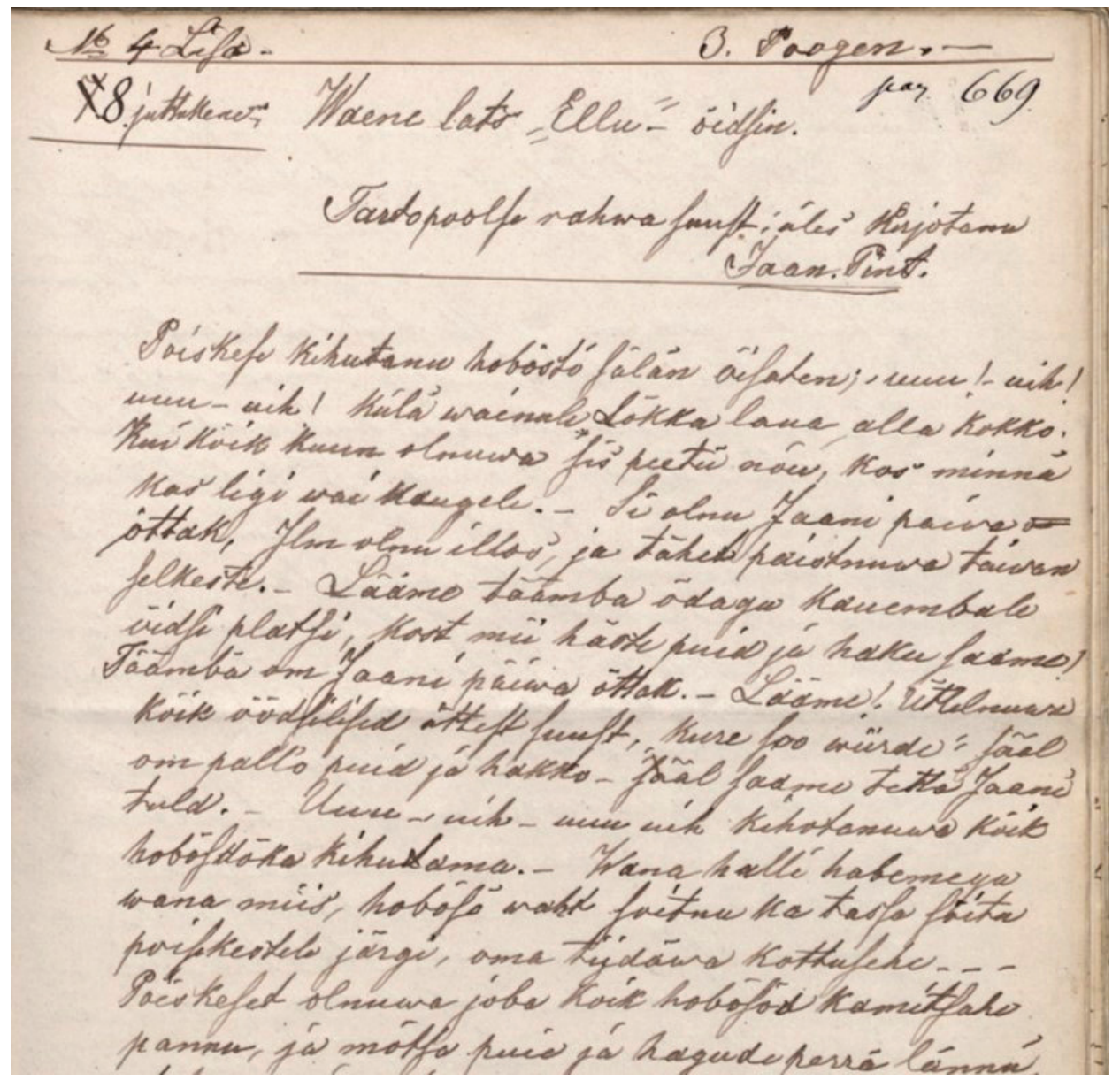

Foto 3. Jaan Pint ei ole oma saadetistele eraldi tiitellehte lisanud. Küll aga on ta iga poogna alguses toonud ära lugude päritolukoha ja üleskirjutaja täisnime. Leheküljel on üks nn kodumurdes lugudest (H II 33, 669).

Pindi kirjapanekud on keeleliselt väga mitmetised. Tema enda nime alt kirjutatud tekstid on väikeste lõuna-eestipärasustega, aga üldiselt pigem kirjakeelsed. Sellest, et rahvaluulet peaks kirja panema murdes, on ta täiesti teadlik, kuid väljendab mitmel pool muret selle teostatavuse üle. Nii kirjutab ta näiteks oma kõige esimese saadetise kaaskirjas: "Keele murdesid palun vabantada, siin ei sa enam iga nurga rahva keele murte järele üles kirjutatud; keele murded on enamasti kõik rahvas ühte liitunuvad, ainult nimisõnasid tahan ma ikka iga 
keele murdes tähendata" (H III 16, 492); sama kordab ka samal aastal saadetud kolmanda saadetise kaaskirjas: “...siin ei sa keele murdelisi juttukeisi teha, Siin on Paabeli segatus ei või uskuda et se kellegi õige oma murre on" (H III 16, 524). Ehk siis: kuna Pint ei viibi ühe konkreetse murde keskkonnas, vaid külas, kus koos eksisteerivad võrdlemisi erineva piirkondliku taustaga eestlased, ei valmista talle muret mitte see, et murre on kirjakeelest liiga erinev, vaid see, et ta ei saa aru, milline üks või teine murre olema peaks. ${ }^{5}$

Olukorra lahendab ta nii, et oma esimestes korjandustes märgib ta kirjapandu juurde ära vaid allika päritolu koha. Näiteks: “Tarto kreisi võnnu kihelkonna rahva suust Korjanud J. Pint” (H III 16, 494). Mõningatel juhtudel on sel moel hõlmatud kogu Eesti: "Ülemal usu kombet on nii samuti üleüldised Tarto, Võro ja Tallinna rahva suust” (H III 16, 539). Hilisemates korjandustes üritab ta siiski ka murdeid kirja panna, kuid muretseb ka siis selle üle, et ta tegelikult ei tea, kas tulemus sai õige:

Tähendus: Need ülemal nimetadud 15 laulu on kõik Lese Paulomägi suu ja keele kõla järele üles kirjutatud [---] Läänemaakonna keelt ma ei tunne. On laulik oma keelt muudnud siis ehk võivad mõned veikesed viiad sisse juhtunudvad (H II 33, 743).

Murde kirjapanekutest märkimisväärseim on Pindi katse panna kirja lugusid keeles, mida kõneldi tema lapsepõlve kodukohas. Pindi viiendas korjanduses on kogum lugusid, mille juures täpsustus: "Tarto Maakonna, Võnnu kihelkonna Ahja poolses keele murete juttustusdes" (H III 16, 661), millele järgneb märkus:

Tähn: Kõik need eel pool juttud on Ahja poolses keele muretes kirjutatud, mis aasta 50 eest tagasi kõnelti. Nüüd vaib kül paljo keele mure muutunu olla.. Ma olen tolle aegse kodo keele kõla järele pü̈̈dnu sõnu üles kirjutada. Mõned väikesed veat on küll sisse juhtunu, kos sulg vähe on eksinu; neid ei ole paljo. Et ma mitme kordse ümber kirjotameseka olen püüdnud vigatest puhastada. - Mitmed sõnad on kül meelega kodo keele puhtusest teisida kirjutatud, mida õigest muido välja kirjutada ei saa-muido kui võõra keele tähtega: Vene keele tähedega - Kõik, siis - - keele kõla järele Kbıik, sbıis - siis on päris kodo keele kõla õige--- (H II 33, 674/5)

Märkuse juures torkab silma, et Pint ei viita kusagil sellele, kelle käest ja mis keeles ta neid lugusid kuulis. Pärinesid need lood tema mälestustest või oli tegu mõne väljarännanud võrukese lugude "tõlgetega"? Seda, et sellist keelt Estonka külas kuulda enam polnud, võib järeldada näiteks Pindi 1894. aastal samast kandist pärit inimestelt kuuldud loole lisatud märkusest: "Jutt on Võru poolse rahva suust kuultud, kes juba Venemaal ligi 40 aastad on elanud, seega ka oma keele juba kirjakeeles muudnud" (H III 22, 613). Igatahes asetab see 
märkus suulise ja kirjalikkuse suhte mõnevõrra paradoksaalsesse valgusesse selleks, et jõuda õige 'keelekõlani' (s.o suulise vormini), tuleb teksti korduvalt ja korduvalt üle kirjutada. ${ }^{6}$

Kodukeele meenutamisest innustust saanuna jätkab Pint järgmisel leheküljel aga hoopiski üldisematel keele teemadel. Kõigepealt võrdleb ta põgusalt Põhja- ja Lõuna-Eesti keele sõnavara. Viimase võtab ta kokku nendinguga: "Nii on palju sõnu veel olemas, millede tähendus kord Tartu keeles selgem ja õigem on, Kord jälle Tallinna keeles õigem" (H II 33, 676). Seejärel liigub ta kohaliku keele teemast aga päris eemale ning ning asub visandama seda, milline võiks olla kõigile eestlastele ühine tuleviku eesti keel. Eesmärgiks seab ta maheda kõlaga keele:

Sulagu moolemad keeled kokku [---] siis saab keele tuum tubli ja kõla kena, kadugu kiinumised ja kääksumised kõrvale, siis saab Eesti keel kena mahe -ja ilus - Suurem albus on kraaksumised ja kriinud laulude laulmise seest kuultaval, kos mon nagu hakk kriunu laulu see on nagu rooste plek halja ihutud riista pääl Tasane kumav keele kõla on soovitav - kasiga kriunumised Eesti keele kõla nurmelt ära! - (H II 33, 676).

Ta möönab, et eks igal rahval oma keel kõige kallim, aga ometi loodab ta, et on võimalik jõuda kokkuleppele:

Igal rahval on oma keel kõige kallim nii ka iga nurga rahval olgu Tartlane, Võruolane, ehk Viru ehk Tallinlane; nõnda peab ka see olema - ometigi peame iga üks järele andma ja ühinema kui meie Eesti keelt õige põhja ja ilususese tahame tõsta siis peame kõik järele andma ja kokku lepima-siis lootame et keel võib oma ilust kätte saada - (H II 33, 676).

Arutluse lõpulõiguga annab ta siiski üsna selgelt ära, kummal poolel tema arust enam õigust on: "Pää jäägu - pea kadugu" (H II 33, 676).

See hüpe intensiivselt ümberkirjutamise kaudu meenutamiselt soovini kohalikest keelelistest eripäradest loobuda oli esimesel korral lugedes võrdlemisi ootamatu. Teisalt võib olla, et just selle meenutusprotsessi kaudu tajus Pint seda, et see osa eesti keelest, mida tema päris omaks peab, on ühiskeeles pigem alaesindatud. Selline üksmeelele kutsumine võis ühelt poolt olla vastuseks neile ajakirjanduslikele nääklustele, millest ma eelnevas kirjutasin; kuid see võis lähtuda ka väljarändajate kogukonna sisemistest probleemidest - võimalik, et nii erineva taustaga kogukonnas olid teatud keelevormid marginaliseeritumad kui teised. 


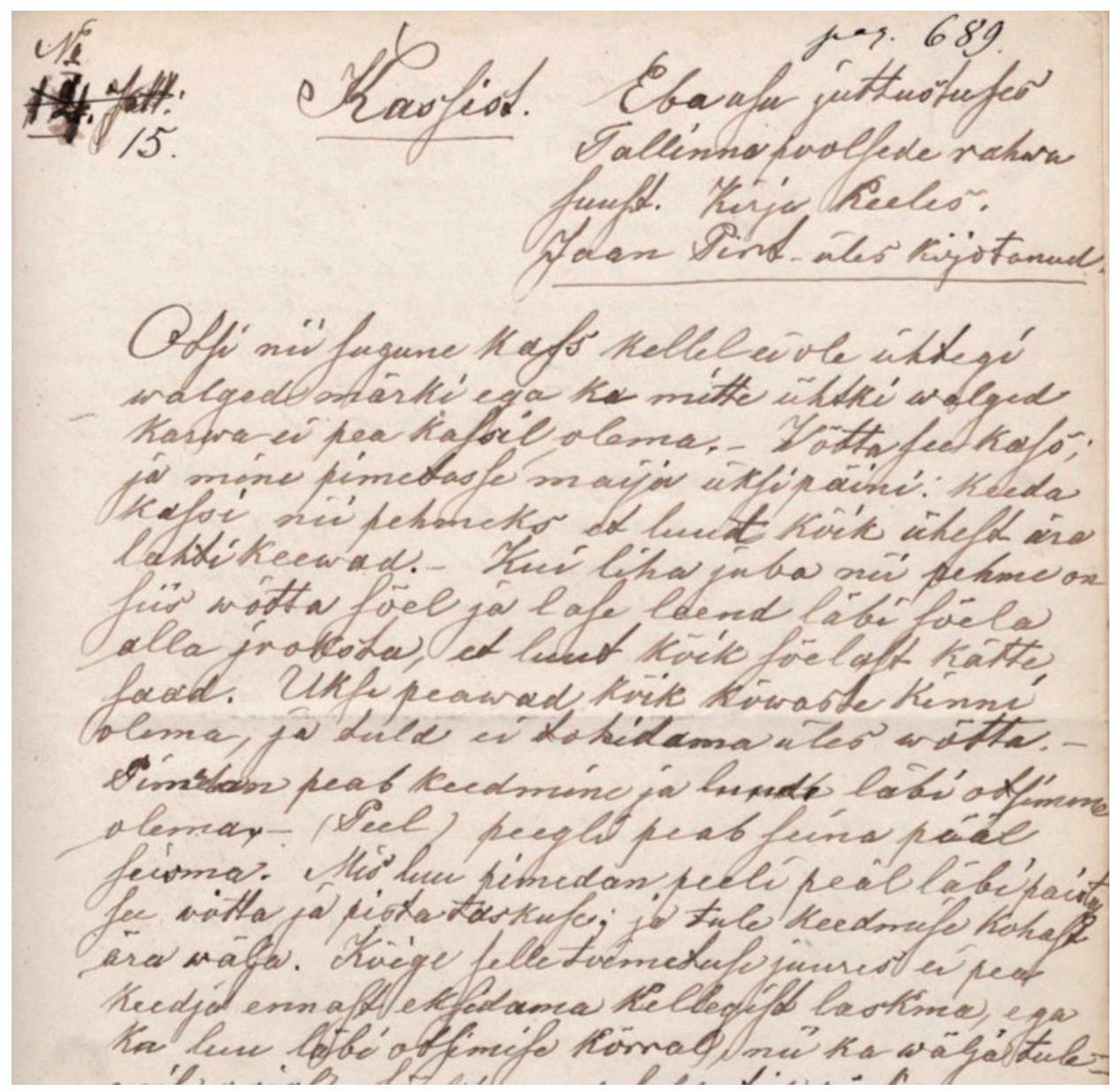

Foto 4. Jaan Pint kogus rahvaluulet väga erineva keelelise taustaga inimestelt. Siin üks lugu, mille ta seob Põhja-Eestiga, kuid mille keelt tajub kirjakeelena (H II 33, 689).

\section{H. A. Schults ja J. Pint: erisused ja ühisused}

Kui palju võime me nende kirjapanekutest järeldada, millises keelelises keskkonnas nad elasid? Eelkõige ehk seda, et Schultsi igapäevane suulise keele kogemus oli homogeensem kui Pindil. Schults veetis pea kogu oma elu ühes paigas (välja arvatud sõjaväeteenistuse aeg) ning ehk seetõttu on tema jaoks eelkõige märgilise tähtsusega erinevus nn vana murde ja uuema (kirjakeelega kohandunud) versiooni vahel, erinevate külade/valdade/kihelkondade keelevorme ta ei erista. Teistest eesti keele aladest viitab Schults vaid rannarahva keelele, näib, et Lõuna-Eesti keelevormidega tal igapäevaelus eriti kokkupuudet ei ole. 
Pint puutus igapäevaelus kokku väga erineva keelelise taustaga inimestega, samas näib, et tema silmis taandus see keeleline paljusus kaheks suuremaks rühmaks: Tartu ja Tallinna keeleks (harvem viitab ta ka maakonnatasandile, sellest madalamale aga vaid enda päritolu puhul). Ehkki me ei tea, mis ajal tema informandid Balti kubermangudest välja rändasid, näib, et pigem oli tegu temasarnaste, juba pikalt diasporaas elanud inimestega - igatahes toob Pint esile, et migratsioonis veedetud aja jooksul on keeled ühtlustunud.

Ent antud artikli seisukohast on sama oluline ka küsimus nende kirjaliku keele kogemusest - sest just kirjutatud sõna tarbimise harjumus oli see, mis nad rahvaluulekogumise kontekstis sümboolselt kõrvu asetas. Seda kogemust mõjutas üheltpoolt kindlasti nende kodukeele suhe kirjakeelega: Schultsi kodukeele ühisosa kirjakeelega oli 58,7\%, Pindil aga 30,7\% (Hennoste \& Pajusalu 2002: 117). Ka on vägagi tõenäoline, et nende kooliõpetus võis toetuda erinevatele materjalidele: kui Schultsi kooliõpetus oli kindlasti põhjaeestikeelne, siis Pint võis õppida lugema lõunaeestikeelsete lugemike abil. Ka oli Pindi nooruses vana kirjaviis ilmselt levinum, kui Schultsi ajal (ehkki ka Schults oli kindlasti puutunud kokku vanas kirjaviisis tekstidega).

Kuigi nende mõlema lugemus oli pigem juhuslik ja katkendlik, püüdlesid nad siiski kirjakultuurist osasaamise poole, seda nii tarbijate kui ka loojatena. Kuna pole võimalik välja tuua kõike, mida üks või teine neist luges, tooksin siinjuures esile kaks kummagi jaoks olulist lugemisvara.

Neist esimene on ajakirjandus. Just tänu ajakirjandusele said nad ju ka teavet rahvaluulekogumise kohta ning tunda end osana rahvaluulekogujate (ja rahvus-) kogukonnast. Samas võis ajakirjandus lisaks ühisele lugemiskogemusele pakkuda ka ühte teistsugust ühiskogemust: ajakirjanduse regulaarne tarbimine võis olla miski, mis eristas neid teistest omakandi inimestest - rahvaluulekogujad toovad sageli esile, et nad on ühed väga vähestest kohalikest ajalehelugejatest (vt nt T. Tetsmanni märkust, H II 20, 887/88). Ehkki Schults ja Pint otseselt seda küsimust ei puuduta, võib oletada, et ka nemad tegutsesid ümbruses, kus aktiivselt kirjakultuuris osalevaid inimesi oli pigem vähe ning kus rahvaluulekogumist alati ei mõistetud.

Teiseks kummalegi mehele oluliseks lugemiselamuseks oli aga Piibel. Schultsi kohta on tunnustavalt märgitud, et ta olla Piibli kolm korda läbi lugenud (ERA II 10, 687), tema arutlustes leidub aga mitmeid otseseid viiteid Piiblile. Pint toob oma eluloos Piiblit esile kui üht nooruspõlve olulisimat lugemiselamust (vt EKLA f 43, m 17: 38, 1 2/3). Piibli puhul on aga põnev see, et erinevalt ajakirjandusest (kui ilmalikust lugemisvarast) oli Piibel (kui religioosne kirjavara) miski, mis ühendas Schultsi ja Pinti mitte üksnes omavahel, vaid ka neid ümbritseva kogukonnaga - seda raamatut hindasid ja lugesid kindlasti ka need, kes ajakirjandusest (jm ilmalikust kirjandusest) lugu ei pidanud. 
Loomulikult tuleb siinjuures meeles pidada, et religioosne kirjavara oli väga tugevalt seotud suulise kultuuriga - s.o paljud, kes pidasid just Piiblit kõige olulisemaks kirjutatud teoseks, tundsid selle sisu eelkõige suuliste vahenduste kaudu. Seda märkimisväärsem on aga see, et Schults ja Pint kaasavad selle suulise ja kirjaliku piirimail oleva ressursi ka oma eestluse ja kirjakultuuriga seotud arutlustesse. Antud artikli teemaga seoses on põnev see, et nad mõlemad seovad keele teema Piiblist tuntud juutide vangipõlve motiiviga.

Schults kasutab seda kujundit, kirjeldades vanade raamatute saatust sakslaste siiatulekul:

Kui juba mua ja rahvas röövlitte saagiks langes, siis matsid ka targad omad pühad usu kirjad nii ära, et ükski võeras seda ei või leida, nagu Jeremia kuldsuitsetamise altari, püha telgi ja seaduse laeka Pabiloni vangi viimise ajal... (H II 67, 440).

Pint omakorda kasutab seda kujundit, et kirjeldada oma suhtumist vanemate poolt pealesunnitud migratsiooni:

Samaras elasin edasi nagu Pabelis ilma rõõmuta.. (EKLA f 43, m 17: $38,13 / 6)^{7}$

Pindi puhul seos keele teemaga mõnevõrra kaudsem kui Schultsil, kuid see on siiski olemas. Nimelt leiab ta, et just väljarändamine võttis temalt võimaluse saada korralikku haridust, reaalselt ühiskonna elus kaasa rääkida. Just see on pannud ta olukorda, kus rahvaluulet tuleb koguda kontekstis, kus "ei sa keele murdelisi juttukeisi teha".

Nagu näha on kujundi funktsioon on Schultsil ja Pindil sama - see rõhutab situatsiooni ajutisust. Nii nagu juudid tulid tagasi, nii tekib ka eestlastel kunagi võimalus oma raamatud jälle välja otsida, ning diasporaa elanikel tagasi kodumaale rännata.

\section{Kokkuvõte}

Jakob Hurda vanavarakogud sisaldavad lisaks vana pärimuse kirjapanekutele ka hulgaliselt vihjeid-viiteid kaasaegsele kultuurile, rahvaluulekogujate elukogemusele, vähese haridusega inimeste kirjalikele praktikatele. Viimaseid võib kirjeldada rahvaliku kirjalikkuse mõiste kaudu - need inimesed pidasid vajalikuks väljendada end kirjalikult, ning seda tehes toetusid nad ühtviisi nii (oma võrdlemisi katkendlikule) kirjakultuurikogemusele kui ka suulisele kultuurile. 
Siinses artiklis seadsin keskmesse kahe rahvaluulekoguja keele- ja kirjateemalised kirjatööd. Tuli esile ühelt poolt see, et Hurda nõue panna materjale kirja 'nii nagu räägitakse' oli kogujatele mitmes mõttes problemaatiline, kuid samas võis just murde eripäradele keskendumine tuua kaasa hoopiski üldisemaid kirjakeele, kirjutamise ja rahvuslusega seotud ideid. Nagu nägime, tulevad Schultsi ja Pindi kirjutistes esile küsimused, mida võib leida ka teiste rahvaluulekogujate tekstidest, ent nende arutlustes on kõnelähedase kirjapanemise tavapärased raskused seotud millegi hoopis laiemaga. Samas on põnev, et üleminek murdedetailide ja üldisemate ideede vahel on neil tuntavalt vastassuunaline.

Schults liigub üldiselt üksikule. Ta alustab lugudega muistsest eesti kirjakultuurist, jõuab küsimuseni tolleaegse kirja kohta ning suundub sealt võrdlemisi sujuvalt ‘tänapäeva kirjaga mittekohanduva' murde kirjeldamise juurde. Jutu taustal on justkui idee, et kusagil peab olema parem/täpsem, just eesti keelele kohandatud tähestik. Schultsi otsingud on ühelt poolt suunatud minevikku just sealt peaks see õige tähestik pärinema. Teisalt on neil ka tulevikuline mõõde - keelt saab mäletada vaid siis, kui teda on võimalik kirja panna; keel, mida ei saa kirja panna, kaob unustusse.

Pint aga liigub üksikult üldisele. Ta alustab oma enda lapsepõlve kodukandi keele meenutamisega - see tegevus on äärmiselt isiklik ja nostalgiline, ta rõhutab, et ei tea, kas seal kuskil seda keelt veel kasutatakse. Lapsepõlve detailidelt liigub ta aga ühiskeele küsimuse juurde. Tema kujutlus ühiskeelest on küll varjamatult tema enda kodukeele poole kaldu ("pää jäägu, pea kadugu”), kuid samas võib see eelistus johtuda ka tajumisest, et see keelevorm on praeguses ühiskeeles marginaliseeritud.

Teatud mõttes on neil kahel mehel üsnagi ühine eesmärk - nad soovivad, et Eesti rahvas oleks tugevam ja ühtsem. Schults leiab, et selle ühtsuse juured peituvad minevikus - minevikulise kirjavara avastamine aitaks meil endid olevikus paremini kehtestada; Pinti aga huvitab eelkõige valmistumine (lähi) tulevikuks. Selle eesmärgi poole püüdlevad nad keelekorralduslike vahendite abil: tõsi - Pint leiab, et reformida tuleks kõnet (s.o jõuda keeleni, milles kõik eestlased end hästi tunneksid), Schults aga peab oluliseks kirja/tähestikku (mis võimaldaks säilitada keelte paljususe ka kirjakultuuris), kuid nende mõlema tulevikuideaaliks näib olevat kirjutatud ja kõneldud sõna vahelise lõhe kadumine, kirja täielik harmoonia keele kõlaga. Ning ehkki nende kirjutajate sõnadel ei olnud jõudu reaalselt midagi mõjutada, on neile siiski kultuuriloolises mõttes oluline tähelepanu pöörata. Nad näitavad seda, kuidas mitte-veel-läbini-kirjalikustunud keskkonnas toimetanud kirjaoskajad piiritlesid suulist ja kirjutatud, olevikulist ja minevikulist keelt. 


\section{Kommentaarid}

1 Artikli valmimist on toetanud Euroopa Liit Euroopa Regionaalarengu Fondi kaudu (Eesti-uuringute Tippkeskus), see on seotud Eesti Haridus- ja Teadusministeeriumi uurimisprojektiga IUT 22-5 ja projektiga EKKM14-389.

${ }^{2}$ Siin on hea võrdluseks viidata Helene Maasenile, kes saksakeelse hariduse tõttu häbeneb oma vähest eestikeelset kirjaoskust: "Palun jällegi neid vigasid vabandata, kelledest mitte puudu ei saa olema, häbi on mull küll nii palju vigasid teha sest ma olen ju üks Eestlane, aga et ma oma emakeele kirjutamist nõnda nagu ütelda varastanud olen, ei mitte koolist õppinud, siis saab see ehk neid vigasid natuke vabandama" (EKLA f 43, m 14: 20, l 10/18).

3 On teateid, et ta tegi kaastöid ajalehtedele, kuid mul pole õnnestunud välja uurida, mida ja millistele ajalehtedele (vt Linda Vilmre kirja Richard Viidalepale ERA II 10, $687(1925)$ ).

${ }^{4}$ Vana vorm Tüürosest. Viiteid sellele rahvale ma rahvajuttudes mujal kohanud pole, Schultsil esineb see päris mitmes jutus ning alati seotuna kirjateemaga (neist lugudest kõige väljaarendatum on H II 39, 381/93 (523). Nimevalikut võib olla inspireerinud näiteks Piibel, või vürst Appoloniuse rännakutest kõnelev haledusjutt (E. Bürow. Vürst Appolonius, Tiiruse, Sidoni ja Antiohia kuningas. Tartu, 1891, 1897).

5 Lisaks murde teemale muretseb Pint kohati ka selle üle, kas kirjapandav üleüldse eesti folkloor on. Näiteks kirjutab ta: "Tähendus: Ülemal juttustuse põhjust maa ei tea - Kas seda Eestlaste seas kodumaal on leida, või on ta siin Venemaal venelaste suust Eestlaste suuse saanud? -" (H II 33, 690).

6 Üsna samamoodi kirjeldab oma kodukihelkonna murde kirjapanemist samuti idadiasporaas elav rahvaluulekoguja Jüri Pihlakas: "Saadetist võin julgesti Jüri kih. Korjanduseks nimetada, sest suurem jagu on hoolega meeldetuletades mineviku mälestustest võetud. [---] Ma olen kõige hoolega rääkijate jutustamise viisi ja korra järel kirjutada püidnud. [---] Sel põhjusel on selle kirjutamine ka piale poole aasta kestnud, et mis mull meeldetuletuse läbi vanast mälestustest elule ärkas ja öö tundidel kui aega juhtusin leidma, üleskirjutada tahtsin - kirjutamise katki pidin jätma ja paiguti nädalate kaupa rääkija kõne viisi ja sõnu veel piinlikumalt meelde tuletama, mis 10-20 aasta eest kuuldud" (EKLA f 43, m 17: 31, 1 1/1-1/2).

7 Sama kujundit kasutab oma olukorra kirjeldamiseks ka Juhan Silbergleich, kes aga rändas välja omal valikul: "Üht haledat rõomu tundmist teeb meile kallilt kodumaalt ära lahkunud ja võera venemaa kubermangudesse elama asunud väljarändanud Eesti üksiku perekondadele Kõik ühised isamaalised tööd, mis suguvennad ja õed kodumaal ühes koos ja ühel nõul korda saatvad, nagu elavalt vana vara korjamine, rõõmustab ja anab troosti kui ajalehest neid sõnumeid loeme, aga ise kui israeli lapsed Pabeli vangis" (H II 33, 209).

\section{Arhiiviallikad}

\section{Eesti Kirjandusmuuseumis:}

EKLA - Eesti Kultuurilooline Arhiiv

ERA - Eesti Rahvaluule Arhiivi rahvaluulekogu (1927-1940)

H - Jakob Hurda rahvaluulekogu (1860-1906) 


\section{Kirjandus}

Barber, Karin 2006a. Introduction: Hidden innovators in Africa. Barber, Karin (toim). Africa's Hidden Histories. Everyday Literacy and Making the Self. Bloomington and Indiapolis: Indiana University Press, lk 1-24.

Barber, Karin 2006b. Writing, genre and a schoolmaster's inventions in the Yoruba provinces. Barber, Karin (toim). Africa's Hidden Histories. Everyday Literacy and Making the Self. Bloomington and Indiapolis: Indiana University Press, lk 385-415.

Barber, Karin 2007. The Anthropology of Texts, Persons and Publics. Oral and Written Culture in Africa and Beyond. Cambridge: Cambridge University Press.

Barton, David \& Hamilton, Mary 2003 [1998]. Local Literacies. Reading and Writing in One Community. London, New York: Routledge.

Burns, Catherine 2006. The Letters of Louisa Mvemve. Barber, Karin (toim). Africa's Hidden Histories. Everyday Literacy and Making the Self. Bloomington and Indiapolis: Indiana University Press, lk 78-112.

Fabian, Johannes 1993. Keep Listening: Ethnography and Reading. Boyarin, Jonathan (toim). Ethnography of Reading. Berkely, Los Angeles, Oxford: University of California Press, lk 80-97.

Grenzstein, Ado 1888. Kes soovib keele harimist? Olevik 22. august, lk 1.

Grenzstein, Ado 1889a. Kuhu sõuda? Olevik 23. jaanuar, lk 1.

Grenzstein, Ado 1889b. "Häbelik Juhan”. Dr. K. A. Hermanni uudisjutt. Kriitikalikult läbi vaadanud A. Grenzstein. Olevik 6. veebruar, lk 2; 13. veebruar, lk 1-2.

Grenzstein, Ado 1889c. Veelgi uut hoogu. Olevik 9. jaanuar, lk 1.

Hennoste, Tiit \& Pajusalu, Karl 2002. Murded ja kirjakeel. Hennoste, Tiit (toim). Eesti murded ja kohanimed. Tallinn: Eesti Keele Sihtasutus.

Hermann, Karl August 1888. Eesti keel. Postimees 20., 22., 24. ja 29. detsember, lk 1.

Hermann, Karl August 1889. Mõnda Eesti keelest. Postimees 14.; 18.; 21.; 25. ja 28. veebruar; 4. ja 11. märts, lk 1 .

Hermann, Karl August 1896. Sumeri-akkadlased: Uurimine wanast muinasajast. Tartu: K. A. Hermann.

Hurt, Jakob 1896. Kurat ja kratt. Postimees 17. veebruar, lk 1-2; Olevik 20. veebruar, lk 2-3.

Hurt, Jakob 1989. Mida rahvamälestustest pidada. Koostanud Ülo Tedre. Tallinn: Eesti Raamat.

Jung, Jaan 1894. Eestikeele jäljed Idamaal. Olevik 25. juuli, lk 1; 8. august, lk 1-2.

Jürgenson, Aivar 2012. Diasporaa eestlaste maastikest. Mäetagused 50, lk 7-28 (doi: 10.7592/MT2012.50.jyrgenson).

Jürgenson, Aivar 2015. Etniline ja rahvuslik. Etnokultuurilistest protsessidest eesti idadiasporaas. Acta Historica Tallinnensia 21, lk 23-50 (doi: 10.3176/hist.2015.1.02). 
Kask, Arnold 1945. Võitlus vana ja uue kirjaviisi vahel. Eesti NSV Tartu Riikliku Ülikooli toimetised 2. Tartu: RK Teaduslik Kirjandus.

Kauranen, Kaisa (toim) 2009. Työtä ja rakkautta. Kansanmiesten päiväkirjoja 18341937. Helsinki: Suomalaisen Kirjallisuuden Seura.

Kikas, Katre 2007. Rahva( ja )luule piiril: Hans Anton Schults Oskar Looritsa ja Richard Viidalepa käsitluses. Kõiva, Mare \& Särg, Taive \& Villandi, Viire (toim). Paar sammukest XXIII. Eesti Kirjandusmuusuemi aastaraamat. Tartu: Eesti Kirjandusmuuseum, lk 7192 (http://www.folklore.ee/rl/pubte/araamat/2007/3katrekikas.pdf-19. märts 2018).

Kikas, Katre 2010a. Rahvaluulekoguja raamatuid otsimas. Hans Anton Schults. Sütiste, Elin \& Salupere, Silvi (koost, toim). Acta Semiotica Estica VII, lk 64-101.

Kikas, Katre 2010b. Hans Anton Schults ja kadunud käsikirjad: rahvalik kirjalikkus rahvaluulearhiivis. Magistritöö. Tartu: Tartu Ülikool.

Kikas, Katre 2016. Rahvajutust ajalugu otsimas. Muinasjutt Rahurikkujast, Siniussist ja Truuvaarist 1890. aasta ajakirjanduses. Labi, Kanni (toim). Paar sammukest XXIX. Eesti Kirjandusmuuseumi aastaraamat 2012-2013. Transmeedialised siirded. Tartu: Eesti Kirjandusmuuseumi Teaduskirjastus, lk 15-42 (doi: 10.7592/PS/29.kikas).

Kingisepp, Valve-Liivi 2001. Eesti keele esimestest kirjapanekutest ja kirjaviisidest. Oma Keel 1, lk 5-13 (http://www.emakeeleselts.ee/omakeel/2001_1/OK_2001-1_01.pdf_ 16. jaanuar 2018).

Koeru $1935=1905$. aasta vabadusliikumine Koeru kihelkonnas. Tallinn: Eesti Rahva Vabadusvõitluse Ajaloo Uurimise Selts.

Krati-raamatu lugeja 1896. Veel "Kurat ja Kratt". Postimees 10. veebruar, lk 3.

Kuismin, Anna 2013. Rahvaan runot. Tuli taas kynälle kyyti. Laitinen, Lea \& Mikkola, Kati (toim). Kynällä kyntäjät. Kansan kirjallistuminen 1800-luvun Suomessa. Helsinki: Suomalaisen Kirjallisuuden Seura, lk 185-214.

Kuismin, Anna \& Driscoll, Matthew James 2013. White Field, Black Seeds. Nordic Literacy Practices in the Long Nineteenth Century. Studia Fennica. Litteraria 7. Helsinki: Finnish Literature Society.

Labi, Kanni 2005. Regilaulukeelest kirjakeeleks. Jakob Hurda kaastöölise vaatepunkt. Emakeele Seltsi aastaraamat 51, lk 38-60 (http://www.emakeeleselts.ee/esa/ESA_51_pdf/ ESA_51_Labi.pdf - 16. jaanuar 2018).

Laitinen, Lea 2013. Näytelmät: Näyttämölle kirjoitettu dialogi. Laitinen, Lea \& Mikkola, Kati (toim). Kynällä kyntäjät. Kansan kirjallistuminen 1800-luvun Suomessa. Helsinki: Suomalaisen Kirjallisuuden Seura, lk 257-298.

Laitinen, Lea \& Mikkola, Kati (toim) 2013. Kynällä kyntäjät. Kansan kirjallistuminen 1800-luvun Suomessa. Helsinki: Suomalaisen Kirjallisuuden Seura.

Loorits, Oskar 2000. Poeedi ja professori prototüübid massis. Runnel, Hando (koost). Meie, eestlased. Tartu: Ilmamaa, lk 352-366.

Nordlund, Taru 2013. Kirjeet. Keskustelua yli ajan ja paikan. Laitinen, Lea \& Mikkola, Kati (toim). Kynällä kyntäjät. Kansan kirjallistuminen 1800-luvun Suomessa. Helsinki: Suomalaisen Kirjallisuuden Seura, lk 107-138. 
Mikkola, Kati 2013. Kansanrunouden kokoelmat. Kerääjinä kuuliaisia avustajia ja visionäärejä. Laitinen, Lea \& Mikkola, Kati (toim). Kynällä kyntäjät. Kansan kirjallistuminen 1800-luvun Suomessa. Helsinki: Suomalaisen Kirjallisuuden Seura, lk 337-378.

Palli, Heldur 1998. Eesti rahvastiku ajaloo lühiülevaade. Tallinn: Sisekaitseakadeemia.

Peebo, Kadri \& Peegel, Juhan (koost) 1989. Igal puul oma juur. Murdetekste Jakob Hurda kogust. Tallinn: Eesti Raamat.

Sayce, A. H. 1900. Piibli ajaloolik tõde Egiptuse, Assiria, Palestiina ja Wäike-Aasia muinasleiduste walguses: Aaastatuhandidte tagant. Jurjew: Kristliku rahwakirjanduse agentur.

Sheridan, Dorothy \& Street, Brian \& Bloom, David 2000. Writing Ourselves. MassObservation and Literacy Practices. New Jersey: Hampton Press inc.

Van Toorn, Penny 2006. Writing Never Arrives Naked. Early Aboriginal Cultures of Writing in Australia. Canberra: Aboriginal Studies Press.

Viidalepp, Richard 1982. Jakob Hurt ja Hans Anton Schultz. Keel ja Kirjandus 5, lk 252-261.

\title{
Summary
}

\section{Recalled language and forgotten literacy: Vernacular language planners in J. Hurt's folklore collection}

\author{
Katre Kikas \\ Researcher, Department of Folkloristics \\ Estonian Literary Museum \\ katreki@folklore.ee
}

Keywords: folklore collection, Hans Anton Schults, Jaan Pint, vernacular language planning

The article focuses on the writings of two men who participated in the folklore collecting campaigns organised by Jakob Hurt. These campaigns started in 1888 and encouraged all people to collect and write down folklore in their area. Texts created by those non-professional (or local) folklore collectors constitute interesting research material language-wise. On the one hand, these texts represent the oral world, on the other they reflect their writers' wish to participate in the public literary sphere of their time.

For Estonians the 19th century was a time of modernisation and national awakening. One part of these processes was the rise of Estonian language in the public sphere and with this the urge to establish the norm of written Estonian (spoken language was divided into very many dialectal variants). Though the main principles of written language were formulated in 1872, when the newly established Society of Estonian Literati started to use the so-called new spelling system in their publications, the lively 
(and heated) discussions about details continued for several decades. Also the issues of writing 'correctly' were quite often a source of quarrels between different newspaper editors - which means that even the least educated newspaper readers knew that written language was a matter for debate.

However, these debates about the Estonian language were something Estonians held themselves, as the Estonian language was not used in the official sphere. Estonia was part of the Russian Empire and local power was exercised by the Baltic Germans so Russian and German were the two official languages. In the middle of the century there were some lower official posts that used Estonian (e.g. village courts), but starting with the Russification reforms in the 1880s everything was converted to Russian. This concerned also education - up to 1887 two lower levels of the educational system (village and parish schools) worked in Estonian, after that Russian became the language of tuition in the entire system.

Thanks to the well-established village school system, the literacy rate of Estonians of the period was quite high; according to the 1881 census, $60.9 \%$ of adults Estonians could only to read, and 34\% could both read and write (Palli 1998: 21-22). These figures refer to their ability to read and write in Estonian - but, as a result of Russification, there were really few opportunities for them to use these skills. Apart from the use in the private sphere, there was a possibility to send short writings to Estonian-language newspapers, or to participate in the folklore collecting campaigns.

Language-wise participation in these campaigns put the collectors in a really ambiguous position. On the one hand, they saw it as a possibility to participate in written communication, on the other hand, they were asked to write down the collected material 'the way it is told', i.e., to retain the dialectal features. For the people who had received only minimal schooling it was quite a challenge, as it meant writing in a way they were taught not to write. But, as a result of these efforts, these people often started to ask questions about the norms of writing and make suggestions in regard to the development of written language. By analogy with the notion of vernacular literacy, I call this phenomenon vernacular language planning.

In the article I analyse two folklore collectors' (or two vernacular language planners') ideas about language and writing; both of them had received only minimal schooling (three years at a village school), but were ardent readers and interested in personal development.

Hans Anton Schults (1866-1905) was born in Järva County and spent almost his entire life there. All his folkloric writings were put down in the local dialect, and it seems that the dialect was rather viable at the time. However, Schults is quite in trouble while trying to convey the dialect in writing and complains about missing letters. Although these kinds of complaints are quite usual among folklore collectors, his explanation to the matter is rather peculiar. He states that the reason lies in the fact that Estonians do not have their own alphabet. Throughout his writings, Schults tries to find evidence that ancient Estonians had viable literary culture, and hopes to reconstruct the alphabet they used for that.

Jaan Pint (1843-1922) was born in southern Estonia, and in 1863 he and his family migrated to Samara. There they lived in the village of Estonka, inhabited by Estonian migrants. So, at the time he started to collect folklore, he had been away from Estonia already for two decades. In his letters to Jakob Hurt he complains that it is not possible 
to record genuine dialects in this village anymore - the inhabitants originate from different areas of Estonia and in the course of time all the dialects have merged. But after some years of collecting he starts to make attempts to convey different dialects. The most notable of these are the tales he states to have written down in his home dialect, i.e., the one that was spoken in the parish where he was born. These texts are purely the work of his own memory - he admits that he rewrote them several times before he was content with the result. But after describing this memory work he starts to contemplate the language situation of Estonians and make suggestions about how to create the most beautiful language out of different dialects. 